\title{
Special section of BPMDS'2015: enabling value creation via business process modeling, development, and support
}

\author{
Selmin Nurcan ${ }^{1}$ - Rainer Schmidt ${ }^{2}$
}

Received: 17 July 2017 / Accepted: 25 July 2017 / Published online: 4 August 2017

(C) Springer-Verlag GmbH Germany 2017

The BPMDS series has produced 11 workshops from 1998 to 2010. Nine of these workshops were held in conjunction with CAiSE conferences. From 2011, BPMDS has become a two-day working conference attached to CAiSE (Conference on Advanced Information Systems Engineering). The topics addressed by the BPMDS series are focused on IT support for business processes. This is one of the keystones of information systems theory. The goals, format, and history of BPMDS can be found on the Web site http://www.bpmds. org/.

\section{Scope}

This special section follows the 16th edition of the BPMDS (business process modeling, development, and support) series, organized in conjunction with CAISE'15, which was held in Stockholm, Sweden, June 2015. BPMDS'2015 received 42 submissions from 25 countries, and 17 papers were selected and published in Springer LNBIP 214 volume.

The theme of BPMDS'2015: "Enabling value creation via business process modeling, development and support" is part of a broader discussion on the value contribution of IT [1]. In the literature, different factors enabling value creation from IT have been identified: appropriate use [2], strategic fit [3], IT assets [1], and IS processes [4]. Following the definition of [5], business process modeling design and support create value by exploiting opportunities and/or neutralizing threats in a firm's environment.

Selmin Nurcan

Selmin.Nurcan@univ-paris1.fr

1 University Paris 1 Panthéon-Sorbonne, Paris, France

2 Munich University of Applied Sciences, Munich, Germany
Value can be created in different areas of enterprises [6]. Value can be defined as the benefit a customer or supplier receives from a product or service. More and more business operators focus on value creation both in the context of creating better value for customers purchasing its products and services and for shareholders in the business who want to see their stake appreciate in value.

Digitization [7] creates disruption in economy and society, and value creation is more critical than ever. Business process owners and senior IT leaders should make value creation explicit to maximize opportunities, minimize threats from digital business disruption, and better meet customer demands.

Increasingly, producer and consumer interoperate in order to co-produce [8-10]. This breaks with the tayloristic [11] aim to separate the consumer from production in order to concentrate production and achieve higher economies of scale only for the producer.

Value creation and BPMDS may potentially influence one another in multiple ways. More than two decades after Hammer and Champy [12] made the explicit link between business processes and value, this relationship is still unclear [13]. Companies seem to be more interested in capturing value from customers than in delivering value to them. Very often, the main reason for a company to have a business process in place that delivers value to a customer is to capture a revenue stream that is indispensable for the company's survival.

BPMDS may interact with value creation either in its entirety or by single disciplines. Value creation may be fostered by new approaches of process modeling, e.g., [14], new process designs [15] or new architectures for business process support [16].

This special section is targeted at both researchers and practitioners in the information systems community with 
a focus on "Enabling value creation via business process modeling, development and support". The six papers in this special section reflect this focus. They are extensively revised and extended versions of research papers that were initially presented at the BPMDS' 2015 working conference and passed again a blind review for the special section.

\section{Six selected papers for this special section}

The first paper by R. Seiger, S. Huber and T. Schlegel, "Toward an execution system for self-healing workflows in cyber-physical systems," presents an integrated system for process execution in cyber-physical systems (CPS). The execution of processes in CPS poses new challenges that cannot be completely handled by current workflow engines. The data-centric and event-driven nature of CPS resulting from the combination of various low-level sensors, actuators, things, and software components requires process execution systems that are able to integrate a heterogeneous set of resources on an active and reactive basis. For CPS, there is a need to handle the dynamics of resource-constraint, loosely coupled devices as well as to support user interactions.

The second paper by T. Baier, C. Di Ciccio, J. Mendling, and M. Weske, "Matching events and activities by integrating behavioral aspects and label analysis," observes that event data, produced by IT services during the execution of a business process, can be used to analyze the process using process mining techniques to discover the real process, measure conformance to a given process model, or to enhance existing models with performance information. The paper presented means to help the analyst to identify the mapping between a process model and events in an event $\log$ in a semi-automated fashion. Defining such a mapping is generally hard to do manually due to its combinatorial complexity. The approach presented leverages insights from behavioral constraints and linguistic analysis to overcome this complexity.

The third paper by S. Leemans, D. Fahland, and W.M.P. van der Aalst, "Scalable process discovery and conformance checking," focuses on two process mining challenges: process discovery and conformance checking. Considerable amounts of data, including process events, are collected and stored by organizations. Authors target techniques to handle billions of events or thousands of activities, to produce sound models, and to guarantee that the underlying process can be rediscovered when sufficient information is available. The paper introduces a framework for process discovery that ensures these properties while passing over the log only once and introduce three algorithms using the framework.

The fourth paper by A. Burattin, V. Bernstein, M. Neurauter, P. Soffer, and B. Weber, "Detection and quantification of flow consistency in business process models," aims to empirically identify key visual features of business process models which are perceived as meaningful to the user and to show how such features can be quantified into computational metrics, which are applicable to business process models. Authors focus on one particular feature, consistency of flow direction, and show the challenges that arise when transforming it into a precise metric.

The fifth paper by C. Haisjackl, P. Soffer, S.Y. Lim, and B. Weber, "How do humans inspect BPMN models: an exploratory study," advocates that we do not have an indepth understanding of how process models are inspected by humans, what strategies are taken, what challenges arise, and what cognitive processes are involved. The paper contributes toward such an understanding and reports an exploratory study highlighting how humans identify and classify quality issues in BPMN process models. It investigates the strategies taken by humans when inspecting a process model, the kinds of challenges that appear during this process, and different manners in which classification is addressed.

The sixth paper by S. Schönig, C. Cabanillas, C. Di Ciccio, S. Jablonski, and J. Mendling, "Mining team compositions for collaborative work in business processes," presents a process mining framework to discover team attributes and composition patterns of collaborative activities in business processes. The approach builds upon a declarative process mining approach focusing on the process resource perspective that has been extended toward the integration of collaborative activities. The described approach first extracts the different teams participating in a collaborative activity from an event $\log$ and then discovers the overall characteristics of the team members in terms of skills, organizational roles, etc., that are present in these teams.

Acknowledgements We wish to thank the referees from the BPMDS'2015 Program Committee members for their timely and accurate reviews during the two-round and blind review process for this special section, namely Eric Andonoff, Karsten Boehm, Lars Brehm, François Charoy, Claude Godart, Chihab Hanachi, Paul Johannesson, John Krogstie, Michael Möhring, Jen Nimis, Geert Poels, Manfred Reichert, Iris Reinhartz-Berger, Stefanie Rinderle-Ma, Shazia Sadiq, Samira Si-Said Cherfi, Isabelle Wattiau, and Jelena Zdravkovic. We would like to thank the Editors-in-Chief of the Journal of Software and Systems Modeling for agreeing to publish this special section. We particularly would like to thank Martin Schindler for his support in helping us put this special section together. Our gratitude goes to all authors of selected papers from BPMDS'2015 who made this special section possible by submitting their work and revising it according to the reviewers' comments.

\section{References}

1. Soh, C., Markus, M.L.: How IT creates business value: a process theory synthesis. In: ICIS 1995 Proceedings, p. 4 (1995)

2. Lucas, H.C., Jr.: The business value of information technology: a historical perspective and thoughts for future research. In: Strategic 
Information Technology Management, pp. 359-374. IGI Publishing Hershey, PA, USA (1993)

3. Grabowski, M., Lee, S.: Linking information systems application portfolios and organizational strategy. In: Strategic Information Technology Management, pp. 33-54. IGI Publishing Hershey, PA, USA (1993)

4. Beath, C., Goodhue, D., Ross, J.: Partnering for business value: The shared management of the IS infrastructure. In: ICIS 1994 Proceedings, p. 40 (1994)

5. Barney, J.: Firm resources and sustained competitive advantage. J. Manag. 17(1), 99-120 (1991)

6. Porter, M.E., Millar, V.E.: How information gives you competitive advantage, Harward Business Review, July (1985)

7. Schmidt, R., Zimmermann, A., Möhring, M., Nurcan, S., Keller, B., Bär, F.: Digitization-perspectives for conceptualization. In: Celesti, A., Leitner P. (eds.) Advances in Service-Oriented and Cloud Computing, pp. 263-275. Springer, Berlin (2015)

8. Payne, A.F., Storbacka, K., Frow, P.: Managing the co-creation of value. J. Acad. Mark. Sci. 36(1), 83-96 (2008)

9. Prahalad, C.K., Ramaswamy, V.: Co-creating unique value with customers. Strategy Leadersh. 32(3), 4-9 (2004)

10. Prahalad, C.K., Ramaswamy, V.: Co-creation experiences: the next practice in value creation. J. Interact. Market. 18(3), 5-14 (2004)

11. Taylor, F.W.: The Principles of Scientific Management, vol. 202. Dover Publications Inc., New York (1911)

12. Hammer, M., Champy, J.: Reengineering the Corporation: A Manifesto for Business Revolution. HarperBusiness, New York (1993)

13. Radhakrishnan, A., Zu, X., Grover, V.: A process-oriented perspective on differential business value creation by information technology: an empirical investigation. Omega 36(6), 1105-1125 (2008)

14. Kueng, P., Kawalek, P.: Goal-based business process models: creation and evaluation. Bus. Process Manag. J. 3(1), 17-38 (1997)

15. Gordijn, J., Akkermans, H., Van Vliet, H.: Business modelling is not process modelling. In: Conceptual Modeling for E-Business and the Web, pp. 40-51 (2000)

16. Weske, M.: Business process management architectures. In: Business Process Management, pp. 333-371. Springer, Berlin, Heidelberg (2012)

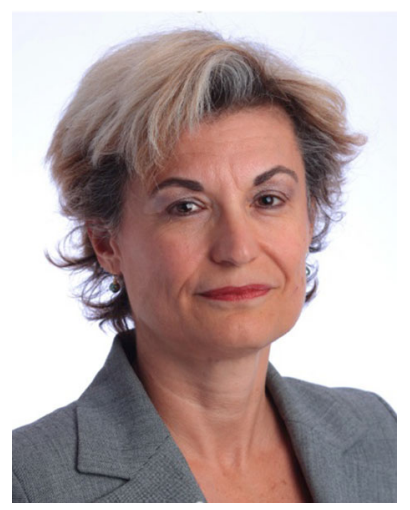

Selmin Nurcan is Associate Professor at the University Paris 1 Panthéon-Sorbonne and a senior researcher at the "Centre de Recherche en Informatique" (CRI). She has a Ph.D. and an engineering degree in computer science. Her research interests include enterprise computing, business process management, change modeling, business/IS alignment, IS governance, process (re)engineering and IS engineering, and CSCW. Selmin Nurcan is co-organizer of the
BPMDS series at CAISE since 2007, the BPMS2 workshop series at BPM since 2008, and the SoEA4EE workshop series at EDOC since 2009. She is serving on the editorial board of several international journals such us International Journal of Information System Modeling and Design, International Journal of Information Systems in the Service Sector, Requirements Engineering Journal, and she is the associate editor of the e-journal on Advances in Enterprise Systems.

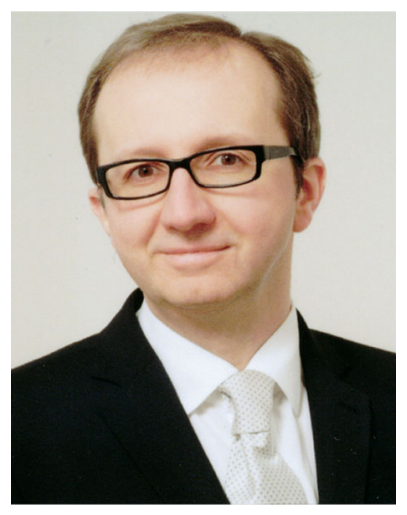

Rainer Schmidt is a professor for business information systems at Munich University of Applied Sciences. He has a Ph.D. and an engineering degree in computer science. His current research areas include service science, enterprise computing, business process management, social software, business/IS alignment, and the integration of these themes. $\mathrm{He}$ has industrial experience as management consultant and researcher. Rainer Schmidt is coorganizer of the BPMDS working conference at CAISE, the BPMS2 workshop series at BPM since 2008, the SoEA4EE workshop series in EDOC since 2009, and member of the program committee of several workshops and conferences. Rainer Schmidt is serving on the editorial boards of International Journal of Information Systems in the Service Sector and International Journal on Advances in Internet Technology. Rainer Schmidt applies his research in a number of projects and cooperation with industry. 